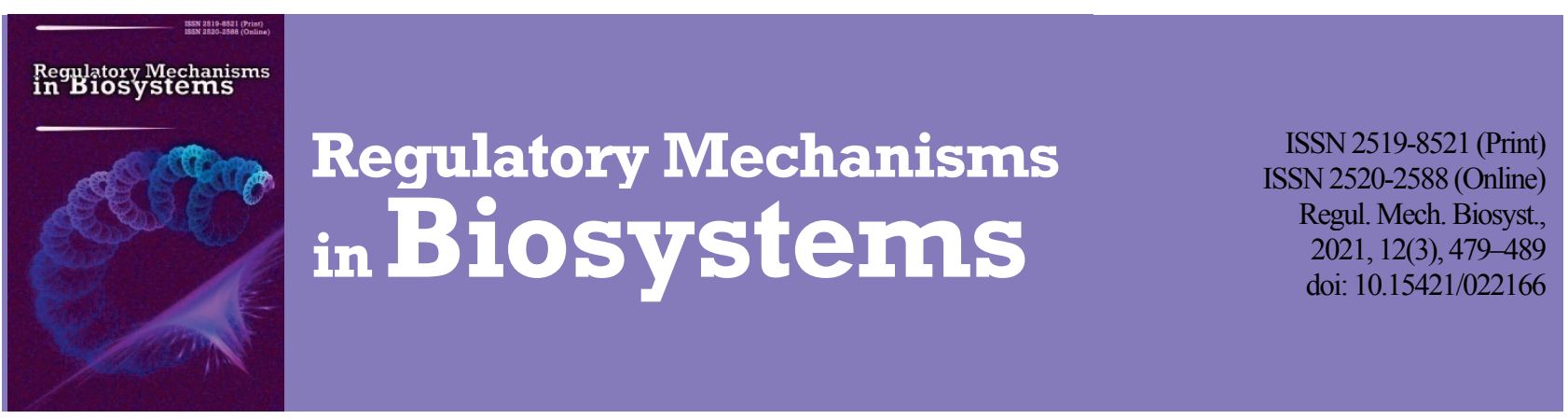

\title{
Intensive animal farming operations and outbreaks of zoonotic bacterial diseases in Ukraine
}

\author{
T. Tsarenko*, L. Korniienko** \\ *Bila Tserkva National Agrarian University, Bila Tserkva, Ukraine \\ **State Scientific and Research Institute of Laboratory Diagnostics and Veterinary and Sanitary Expertise, Kyiv, Ukraine
}

Article info

Received 25.06.2021

Received in revised form 20.07.2021

Accepted 21.07.2021

Bila Tserkva National Agrarian University,

Soborna st., 8/1,

Bila Tserkva, 09117,

Ukraine.

Tel.: +38-068-353-63-69.

E-mail:

taras.m.tsarenko@

gmail.com

State Scientific and Research Institute of Laboratory Diagnostics and Veterinaryand

Sanitary Expertise,

Donetska st., 30,

Kyiv, 03151, Ukraine.

Tel.: +38-073-306-01-86.

E-mail:

leonid.kornienko.09@

gmail.com

\section{Tsarenko, T., \& Korniïenko, L. (2021). Intensive animal farming operations and outbreaks of zoonotic bacterial diseases in Ukraine. Regulatory Mechanisms in Biosystems, 12(3), 479-489. doi:10.15421/022166}

In Ukraine zoonoses are a permanent threat to human health, some of them are bacterial diseases associated with farm animals. Complete avoidance of outbreaks of bacterial zoonoses is not possible but it is appropriate to study them to reduce the risks of transmission of zoonosis pathogens from industrial farms to the human population and the environment. The article highlights the results of a literature review on the potential role of industrial livestock farms in the spread of major bacterial zoonoses in Ukraine. About half of all of the country's farmed animals are kept on farms using industrial technology; more than half of the establishments are classified as medium and large. The technology of keeping animals on such farms contributes to the development of diseases of obligate hosts caused by fecal bacteria. The systematic search and selection of literary sources, which are relevant to the topic of the study were carried out. The vast majority of analyzed publications are published in Ukrainian in local peer-reviewed scientific journals. An analysis of open-access official statistics from the state authorities of Ukraine was also conducted. The authors analyzed statistics and scientific papers published over the last 10-15 years discussing the outbreaks of food-borne zoonoses among humans and the studying their pathogens (Campylobacter spp., Salmonella spp., Escherichia coli (STEC strains), Listeria spp.) on industrial livestock farms. The main source of Campylobacter spp. and Salmonella spp. distribution are industrial poultry, including broilers and chickens, respectively. The STEC strains $E$. coli carriers are various types of farm animals, including cattle and pigs. The majority of infections documented in Ukraine are cases of salmonellosis in humans and animals. Despite reports of a significant prevalence of campylobacteriosis, colibacillosis and listeriosis in livestock farms, their association with outbreaks of food-borne zoonoses in humans remains poorly understood. The concept of an industrial livestock farm involves a permanent presence of a risk of outbreaks of bacterial zoonoses and their rapid spreading to the human population. This is due to concentrated maintenance of animals, standardized feeding, the priority of achieving the highest productivity of animals and economic indicators. Under such conditions, disturbance of hygienic norms and technologies significantly increases the risk of bacterial zoonoses on industrial farms. It is important to enforce the continuous control of the level of microbial pollution of farms, animal health, hygiene of milk production and processing, meat, eggs, etc. Farms have a negative impact on the ecological welfare of the surrounding territories. The problem of spread of antibiotic-resistant strains of bacterial zoonoses is a very serious one. Efforts for the formation of a national system of epidemiological supervision over bacterial zoonoses, comprising epidemiological, epizootological, ecological, microbiological, serological and molecular genetic monitoring, as well as the development on this basis of effective prophylactic and anti-epidemic measures are relevant and necessary.

Keywords: intensive animal farming; zoonoses; Campylobacter spp.; Salmonella spp.; E. coli (STEC strains); Listeria spp.

\section{Introduction}

Today, animal husbandry in Ukraine is well-developed, with a structure consisting of dairy and beef cattle, poultry, pigs, sheep and goats, as well as, to a lesser extent, rabbit breeding and fur farming. Beekeeping and aquaculture are also present. Animal husbandry is developed in all regions of the country. Historically, the structure of animal husbandry in Ukraine was shaped by the USSR and mainly comprised medium-sized collective farms and household plots. For example, in 1983, relative to total production, private producers in Soviet Ukraine accounted for 34\% of meat, $26 \%$ of milk and 38\% of eggs (Wädekin, 1990).

Over 30 years, the number of farmed animals in Ukraine has declined: cattle by $87.4 \%$, including cows by $78.7 \%$, pigs by $70.5 \%$, small ruminants by $85.7 \%$, poultry by $10.4 \%$ (Table 1 ). Only the poultry industry has recovered after an almost $50.0 \%$ decline, primarily due to the production of broiler meat, which accounts for a significant share of the meat market in Ukraine. As of December 1, 2020, there were 3.15 million head of cattle in Ukraine, including 1.73 million cows, 6.12 million head of pigs and 1.27 million head of small ruminants. The number of poultry was
218.93 million (State Statistics Service of Ukraine, 2019, 2020a, 202b). In the new economic conditions, the only way to maintain the industry was to increase the productivity of animals by intensifying production processes. As a result of the gradual change in technologies of production of cattle breeding, pig breeding and poultry farming from extensive to intensive new factors appeared that can potentially affect the stability of the sanitary situation on farms and enhance the influence of such farms on the environment, including the spread of pathogens of bacterial zoonoses. Currently, there is a complex situation in the development of livestock breeding due to protracted military actions, pandemic and prolonged crisis (Lavruk \& Lavruk, 2020). Economic reasons underlie a decrease in some farms of biosafety standards and sanitation. At the same time, there is a reform of sanitary supervision of infectious diseases and public health systems in Ukraine. All this against the backdrop of insufficient financing of state control bodies creates many risks for distribution of pathogens of zoonosic diseases from livestock industrial farms to people and new outbreaks of zoonotic diseases.

All regions of Ukraine have farms with the main species of farm animals raised in the country, these are cattle (including cows), pigs and 
poultry (broilers and laying hens), to a lesser extent goats and sheep. The farm animals are not evenly distributed, among the leaders in the terms of major species of animals are Lviv region in the west, Zhytomyr, Kyiv and Vinnytsia regions in the center and the Dnipropetrovsk region in the east of Ukraine. In some regions, there may be significantly more specific species of farm animals than others, for example poultry in Vinnitsa region or pigs in Donetsk region. This is due to the presence of large industrial animal husbandry enterprises in the region (Fig. 1).

\section{Table 1}

Number of farm animals in all categories of farms in Ukraine, thousand head (according data from statistical compendiums of State Statistics Service of Ukraine)

\begin{tabular}{cccccc}
\hline Years & Cattle & $\begin{array}{c}\text { Including } \\
\text { cows }\end{array}$ & Pigs & $\begin{array}{c}\text { Sheep } \\
\text { and goats }\end{array}$ & Poultry \\
\hline 1990 & 24623.4 & 8378.2 & 19426.9 & 8418.7 & 246104.2 \\
2000 & 9423.7 & 4958.3 & 7652.3 & 1875.0 & 123722.0 \\
$2001-2005$ & 7931.7 & 4295.7 & 7682.7 & 1838.4 & 148281.4 \\
$2006-2010$ & 5213.3 & 2933.3 & 7427.6 & 1717.4 & 181732.7 \\
$2011-2015$ & 4248.0 & 2414.9 & 7460.4 & 1581.8 & 212488.6 \\
2015 & 3750.3 & 2166.6 & 7079.0 & 1325.3 & 203986.2 \\
2016 & 3682.3 & 2108.9 & 6669.1 & 1314.8 & 201668.0 \\
2017 & 3530.8 & 2017.8 & 6109.9 & 1309.3 & 204830.9 \\
2018 & 3332.9 & 1919.4 & 6025.3 & 1268.6 & 211654.4 \\
2019 & 3092.0 & 1788.5 & 5727.4 & 1204.5 & 220485.8 \\
2019 to $1990, \%$ & 12.6 & 21.3 & 29.5 & 14.3 & 89.6 \\
\hline
\end{tabular}

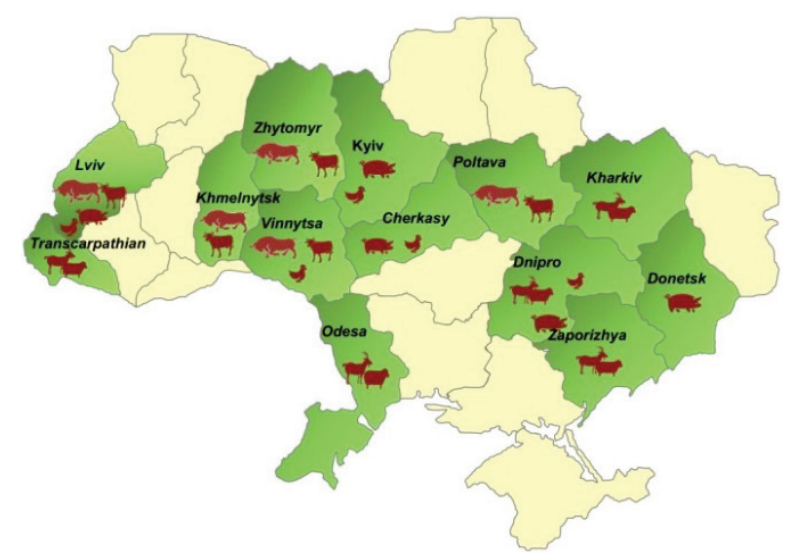

Fig. 1. TOP-5 regions of Ukraine by the number of farm animals, as of December 1, 2020 (source: Ministry for Development of Economy, Trade and Agriculture of Ukraine, based on data of State Statistics Service of Ukraine)

The stock of farm animals in Ukraine traditionally been divided into two types: household and industry. Household animal husbandry is the breeding of productive animals near the owner's home, the purpose of which is not always economic benefit (Fig. 2). However, household cattle breeding, as well as milk production, is twice as great as industrial breeding (Fig. 3). In pigs and poultry industrial farms predominate and most of the meat and eggs in Ukraine are produced by such enterprises.

Industrial agricultural enterprises are classified by the number of animals and scale of production on small, medium and large farms. For livestock farms, small farms are those which hold up to 100 animals, average farms 100-999 animals and large farms more than 1000 animals, for pig farming, this gradation will be respectively 100-199, 200-4999, more then 5000 pigs. The latter is the predominant factor that determines the technology of keeping animals and obtaining livestock products, including safety and quality control procedures. According to the State Statistics Service of Ukraine (www.ukrstat.gov.ua), as of January 1, 2020, about half the farms keeping various species of animals were medium and large establishments. $62.5 \%$ of farms keep more than 100 head of cattle, and $55.0 \%$ of farms keep more than 100 dairy cows. More than 200 pigs are kept on $55.1 \%$ of farms, more than 5,000 poultry on $62.1 \%$ of farms, and on more than $37.1 \%$ of poultry farms the number of birds exceeds 50,000 . Such farms are characterized by a high concentration of animals, application of standard technologies and use of industrial equipment at all stages of animal breeding and exploitation. Specialists in animal husbandry technology and veterinarians are engaged on all farms. Additionally, the state veterinary service controls veterinary preventive and anti-epizootic measures, as well as outbreaks of infectious diseases (Pidpala et al., 2018). Nevertheless, such farms are at the highest risk of outbreaks of bacterial zoonoses of obligate hosts. The technology of keeping and exploiting animals, especially when not applied properly, causes favourable conditions for the reproduction and spread of bacterial pathogens, while weakening the animals' resistance (Lytvyn et al., 2002).

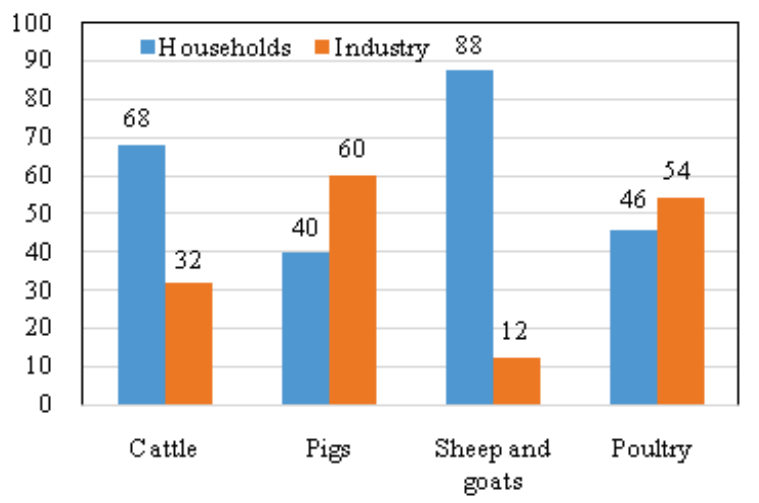

Fig. 2. Percentage of farmed animals in Ukraine by farm categories as of December 1, 2020 (source: Ministry for Development of Economy, Trade and Agriculture of Ukraine based on data of State Statistics Service of Ukraine)

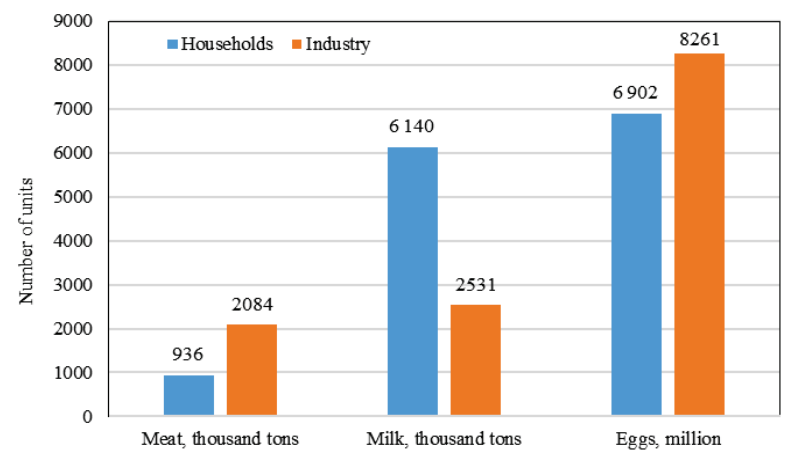

Fig. 3. Production of livestock products by farm categories in January-November 2020 (source: Ministry for Development of Economy, Trade and Agriculture of Ukraine based on data of State Statistics Service of Ukraine)

The World Health Organization (WHO), the Food and Agriculture Organization (FAO), and the World Organization for Animal Health (OIE) define zoonoses as diseases that can normally spread from vertebrates to humans. In this case, animals can be both a reservoir of infection and a certain part of its path to humans (Hallaj, 2010). A total of 1,415 species of microbial and parasitic agents cause diseases in humans, including most of all, bacteria and rickettsiae -538 species, fungi -307 species, 217 species of viruses and prions, 287 helminths and 66 protozoa. Of the total number of pathogens, $868(61.0 \%)$ are zoonoses (Taylor et al., 2001). Bacterial zoonoses are transmitted from animals to humans through direct contact or contaminated materials. In the context of public health, transmission of infectious agents through food (food-borne) and food poisoning by bacterial toxins (toxicoinfections) are the most crucial ones. The main livestock products that carry the risk of zoonotic diseases are raw meat, milk and eggs, as well as products made from them, such as sausages, cheeses, etc. (Cutler, 2015; Morwal, 2017). Zoonoses are a threat to human health and life, and can have a significant impact on public health. Also, economic losses are incurred in case of animal diseases that require treatment, culling or destruction of products made from sick animals. Human disease creates a social and economic burden due to temporary unfitness for work and the need for additional government spending on the elimination and prevention of zoonoses (Berthe et al., 2013; Casey et al., 2015; Antunes et al., 2019). According to the latest available 
data from the European Food Safety Authority and the European Centre for Disease Prevention and Control, in 2018, in 36 countries of Europe, the main bacterial zoonoses were campylobacteriosis, salmonellosis, colibacillosis caused by Shiga toxin-producing Escherichia coli (STEC), yersiniosis and listeriosis, which occur when food is contaminated with pathogens of these diseases or when people come into contact with sick animals and contaminated environment (EFSA, 2019).

In Ukraine, the State Veterinary Service, which is part of the State Service of Ukraine for Food Safety and Consumer Protection (SSUFSCP) is responsible for controlling zoonoses among animals. The State Institution "Public Health Centre of the Ministry of Health of Ukraine" carries out surveillance and prevention of, as well as response to human zoonoses. The institution is a healthcare facility responsible for maintaining and strengthening the health of the population, as well as for social and hygienic monitoring of diseases, epidemiological surveillance and biological safety, preventing diseases in groups and populations, control of epidemics and strategic management in the field of public health. Each of these institutions does its own reporting, so consolidated reports and data analyses are not available. Among bacterial zoonoses, monitoring of bovine tuberculosis, brucellosis, anthrax, leptospirosis and salmonellosis by the state veterinary service is mandatory. In addition, mandatory annual serological tests of all cattle and small ruminants for brucellosis, as well as monitoring serological study of cattle (5-10\% of the total population) for leptospirosis are performed, and the State Programme for the Control of Avian Salmonellosis has to be followed. It provides for regular laboratory tests aimed at detecting and preventing salmonellosis infections on poultry farms. Health system reporting involves the collection and consolidation of human cases of infectious diseases, including bacterial zoonoses. The reports are published on a monthly basis by the state institution "Center for Public Health of the Ministry of Health of Ukraine". Given the lack of structured data, a developed system for monitoring bacterial zoonoses and analytical materials, as well as selective research by various authors performed in recent decades are important sources for analysing the problem.

The aim of the study was to perform systematic analysis of the literature on the prevalence of bacterial zoonoses among the human population and farmed animals, identifying risk factors associated with industrial livestock farming and assessing its potential role in the spread of bacterial zoonoses in Ukraine.

\section{Criteria for collecting and selecting sources for analysis}

For the purpose of this study, the authors analysed publications according to a scheme similar to those recommended for systematic review (Gupta et al., 2018). Studies that could fully or partially reveal the potential role of intensive livestock farming in the emergence of bacterial zoonoses in Ukraine were selected. Publications published in 2010-2020 were selected (in some cases, papers published after 2000 were also included).
Scientific articles and official reports of the Veterinary Service, the Ministry of Health of Ukraine, and other competent authorities were selected from all sources of information. Sources in the Ukrainian, Russian and English languages were analysed. The criteria for selecting studies for analysis were as follows: survey papers, experimental papers or publications describing clinical cases; studies concerning Ukraine and containing data that allow one to draw conclusions about the prevalence of the disease, epidemiological features and the potential role of intensive livestock farming in the spread of the disease. To be included in the study, sources had to come from peer-reviewed scientific journals, research had to be methodologically correct and not show signs of bias and conflict of interest.

For the literature search, the following were used: the national database of scientific literature, national database of scientific journals "Science Periodicals of Ukraine" (www.irbis-nbuv.gov.ua), international database: Google Scholar (www.scholar.google.com.ua) PubMed (www.pubmed.ncbi.nlm.nih.gov), Web of Science (www.webofknowledge.com) and Scopus (www.scopus.com).

The following list of diseases was selected for analysis: campylobacteriosis (Campylobacter spp.), salmonellosis (Salmonella spp.), escherichiosis (including STEC), listeriosis (Listeria spp.), which corresponds to the list of diseases monitored in the European Union (EFSA, 2019). Search queries for each pathogen followed the pattern: "pathogen or disease" + "animal species" + "Ukraine" in each of the languages. All papers found in the databases were filtered for compliance with the research topic and the compliance and quality criteria. As a next step, materials were reevaluated qualitatively and, finally, included in the list of materials for analysis. Based on the analysis of selected materials, a critical review of the literature on the subject matter was formed and conclusions about the potential role of intensive animal husbandry in outbreaks of zoonotic bacterial diseases in Ukraine were formulated.

As a result of a search conducted according to the method described above and upon filtering publications for analysis, only 111 publications were selected, 15-41 for each disease in Ukrainian and Russian (cyrillic). The Google Academy search engine had the largest coverage of "cyrillic" publications, and the national database of scientific journals "Scientific Periodicals of Ukraine" was the most accurate. Statistical data on the diseases under study available from competent state bodies on an open-access basis tended to be limited and inconsistent (Table 2).

The number of cases of campylobacteriosis and listeriosis in humans reported during 2018-2020 remained on a steady level, whereas the number of cases of salmonellosis decreased twofold. Data on animal morbidity and the number of contamination points are available only for salmonellosis and mainly reflect the results of salmonellosis monitoring on poultry farms according to the State Salmonellosis Monitoring Programme, which explains the large number of sick animals, considering that poultry farms in Ukraine mostly keep large numbers of birds.

Table 2

Human and animal morbidity rate of the main bacterial zoonoses in Ukraine in 2018-2020 (according to official statistics from state institution "Center for Public Health of the Ministry of Health of Ukraine" and The State Service of Ukraine on Food Safety and Consumer Protection)

\begin{tabular}{|c|c|c|c|c|c|c|c|c|c|c|}
\hline \multirow{3}{*}{ Zoonotic disease } & \multicolumn{6}{|c|}{ Morbidity among people } & \multicolumn{4}{|c|}{ Morbidity among animals } \\
\hline & \multicolumn{2}{|c|}{ for 11 months of 2018} & \multicolumn{2}{|c|}{ for 11 months of 2019} & \multicolumn{2}{|c|}{ for 11 months of 2020} & \multicolumn{2}{|c|}{ January-December 2018} & \multicolumn{2}{|c|}{ January-December 2019} \\
\hline & $\begin{array}{l}\text { number } \\
\text { of cases }\end{array}$ & per 100,000 & $\begin{array}{l}\text { number } \\
\text { of cases }\end{array}$ & per 100,000 & $\begin{array}{l}\text { number } \\
\text { of cases }\end{array}$ & per 100,000 & farms & $\begin{array}{l}\text { sick animals } \\
\text { (head) }\end{array}$ & farms & $\begin{array}{l}\text { sick animals } \\
\text { (head) }\end{array}$ \\
\hline Campylobacteriosis & 136 & 0.3 & 146 & 0.4 & 138 & 0.3 & $\mathrm{n} / \mathrm{a}$ & $\mathrm{n} / \mathrm{a}$ & $\mathrm{n} / \mathrm{a}$ & $\mathrm{n} / \mathrm{a}$ \\
\hline Salmonellosis & 7452 & 17.6 & 8150 & 19.3 & 3621 & 8.6 & 5 & 647494 & 6 & 275012 \\
\hline Listeriosis & 2 & 0.0 & 2 & 0.0 & 1 & 0.0 & $\mathrm{n} / \mathrm{a}$ & $\mathrm{n} / \mathrm{a}$ & $\mathrm{n} / \mathrm{a}$ & $\mathrm{n} / \mathrm{a}$ \\
\hline
\end{tabular}

\section{Campylobacteriosis (Campylobacter spp.)}

Campylobacteriosis is caused by the Campylobacter bacteria, i.e. consumers residing in the intestinal tract of many animals, including poultry, pigs and ruminants. Campylobacter are gram-negative curved rods that move in a characteristic corkscrew motion, and do not form spores and capsules. The Campylobacter series includes about 20 species, but the C. jejuni and C. coli species are of the greatest importance in the etiology of campylobacteriosis (Facciolà et al., 2017; Chlebicz \& Śliżewska, 2018). Broilers, as the main source of infection, play the largest role in the etiology of campylobacteriosis in humans. Bacteria Campylobacter spp. colonize the digestive tract of chickens during their first two weeks of life, and without causing any symptoms are released into the environment in large quantities with feces until slaughter (Schiaffino et al., 2019). In European countries, campylobacteriosis is the most common cause of infectious gastroenteritis. According to EFSA and ECDC, 246,571 cases of human campylobacteriosis were documented in the EU in 2018, with an average incidence rate of 64.1 per 100,000 population, with $99.6 \%$ of campylobacteriosis outbreaks being of food origin and resulting from consumption of contaminated milk and broiler meat (EFSA, 2019). According to the Centre for Public Health of the Ministry of Health of Ukraine, the average incidence of campylobacteriosis in 2018-2020 was 
only $0.32-0.35$ per 100,000 population. Such a significant difference in the incidence of campylobacteriosis in humans should be attributed to the imperfect diagnosis of the disease in Ukraine due to the absence of a developed system of surveillance and notification rather than to an improved epidemiological situation (Kyryk, 2012a, 2016; Pinchuk \& Pustovit, 2018). For example, studies conducted in 2000-2009 show that campylobacterriosis was detected in sick children in $1.0 \%$ of cases in $2000 ; 3.0 \%$ in 2005, and up to 5.0\% in 2009 (Tarasenko, 2011), while 50-60 thousand cases of infectious diarrhea in children are detected in Ukraine per year (Andrukh, 2015). Epidemiological studies from 2013 showed that the proportion of patients with campylobacteriosis among 26,707 patients with acute intestinal infections was $1.9 \%$ (Kyryk, 2013). It should also be noted that in 2018-2020, 15,508-48,554 cases of acute intestinal diseases of unknown etiology were confirmed in Ukraine, i.e. an intensity of 36.94-114.47 per 100,000 population.

An analysis of 90 strains of Campylobacter spp. of different origin: clinical isolates, "chicken" strains and strains from environmental objects (30 strains from each group) detected in Ukraine in 2011 showed that $31.6 \%$ of the strains were highly cytopathogenic, i.e. the most dangerous for humans, while $53.1 \%$ were cytopathogenic and $15.3 \%$ were acytopathogenic. The largest number of highly cytopathogenic strains was among isolates from clinically ill people $-52.6 \%$. Among farm animals, the largest percentage of highly cytopathogenic strains were detected in chickens $44.1 \%$, calves $-30.0 \%$, and pigs $-29.4 \%$. A smaller number of highly cytopathogenic strains of campylobacter was found among those isolated from wastewater (16.7\%) and open water (10.0\%) (Kyryk, 2011).

In 2012, as a result of an extensive epidemiological survey of 216 foci of campylobacteriosis, analysis of 1569 samples from animals of different species, birds, and environmental objects, including wastewater from the equipment of meat and poultry processing enterprises, bacteria of the genus Campylobacter were detected in the intestines of cattle in 13.3\%, pigs $-20.5 \%$, ducks $-25.6 \%$ of the cases. Regular examination of chickens in poultry farms in the Zaporizhia and Kyiv regions has proven that the Campylobacter contamination rate of slaughtered chickens ranged from $28.0 \%$ to $33.7 \%$. The contamination of chicken carcasses with Campylobacter was at the level of 18.2-20.0\%. Campylobacter was found in $20.0 \%$ of chicken manure samples. Chickens were the main source of infection in outbreaks of campylobacteriosis in humans (38.2\%), the spread of the disease in family households was confirmed in $34.2 \%$ of cases. In $79.1 \%$ of cases, the infection was transmitted through food (meat, eggs, milk), and in $20.9 \%$ of cases - through water. Of great epidemiological significance in the spread of campylobacteriosis in humans is Campylobacter contamination of slaughter chickens (29.6\%), ducks (25.6\%), pigs (20.5\%), cattle (13.1\%), as well as environmental objects: poultry farm wastewater $(35.7 \%)$, meat processing enterprises $(20.0 \%)$ and reservoirs that partially receive wastewater $(12.5 \%)$. It was also found that pigs are the main carriers of Campylobacter coli $(61.8 \%$ of isolated strains) (Kyryk, 2012b). In other studies, the circulation of campylobacteriosis pathogens was determined at $30.0 \%$ in the studied poultry and $20.0 \%$ in cattle (Babkin, 2013). The circulation of Campylobacter in the population of farm animals and the environment creates epidemic foci of the disease and increases the incidence of the disease in humans (Kyryk, 2012b).

There is a need for systemic epidemiological surveillance of campylobacteriosis, which includes epidemiological, epizootiological, environmental, microbiological, serological, and molecular genetic monitoring, as well as the development of effective preventive and anti-epidemic measures on that basis (Kyryk, 2017). One of the sources of difficulties in ensuring effective surveillance of campylobacteriosis is the relatively complex bacteriological and biochemical diagnosis of the pathogen (Drahut, 2013) which is the main method of detecting and identifying campylobacter (Babkin \& Kalinichenko, 2010; Lapa et al., 2015).

Monitoring the incidence of Campylobacter spp. in farmed animals as well as checking slaughter products for contamination is essential for controlling the risks of human campylobacteriosis. Numerous studies indicate that in Ukraine, there is a problem of Campylobacter spp. contamination of livestock products, which is confirmed by the fact that similar strains of pathogens are detected in both sick people and food, indicating their wide circulation in the environment (Fotina et al., 2018). One of the main ways in which broiler meat becomes contaminated with Campylobacter is by contamination of carcasses during slaughter. $C$. jejuni is detected in $8.0-21.8 \%$ of samples of caecal contents of slaughter birds, while for $C$. coli the number ranges from $2.4 \%$ to $8.0 \%$. The detection rate of Campylobacter spp. in wastewater from washing the cages in which the poultry was transported to the slaughterhouse was $4.0-8.0 \%$ (Kasianenko et al., 2019). In another study, the detection rate of Campylobacter spp. in the intact caecum of broilers was $7.5 \%$, and in wastewater from washing the carcasses it was $4.5 \%$ (Rodionova, 2017). Variable levels of excretion of microorganisms of the genus Campylobacter were found in other studies of poultry in slaughterhouses at different stages of processing of healthy and sick birds: from the surfaces of carcasses isolated before gutting $-1.1 \%, 4.1 \%$; from the surfaces of poultry carcasses after gutting $5.9 \%, 14.5 \%$; from the content of the cecum $-6.4 \%$ and $19.2 \%$; from poultry carcasses after washing $-5.1 \%$ and $18.1 \%$; from poultry carcasses after cooling $-3.2 \%$ and $14.6 \%$, respectively. Isolates of Campylobacter spp. were were presented to the following serotypes by $C$. jejuni-77.1\%, C. coli-21.1\% and C. lari-1.9\% (Kasianenko, 2012).

Campylobacter jejuni bacteria has an expressed resistance to low temperatures, although the number of viable Campylobacter decreases over time when meat is frozen: 2.5 times after 30 days and 11.8 times after 60 days. The culture of $C$. jejuni is capable of forming morphologically altered colonies of R-forms, and in cooled meat - colonies characterized by S-forms (Kasianenko, 2009). During the cooling and freezing of poultry carcasses, the risk of cross-contamination of their surfaces increases. Campylobacter jejuni strains detected on the surface of poultry carcasses have been found to be pathogenic for laboratory animals and laying hens (Kasianenko et al., 2017), confirming their epidemiological and epizootiological significance in the context of carcass contamination during slaughter. Such risks require compliance with cleanliness and sanitary norms at slaughterhouses and processing enterprises; refraining from feeding poultry before slaughter, which may slightly reduce the level of contamination of transport and equipment of slaughterhouses (Kasianenko et al., 2019); prevention of rupture of poultry intestines at slaughter, fixation of the cloaca, prevention of fecal release (Kasianenko \& Gusjev, 2019). Methods are proposed to reduce contamination of poultry carcasses by treating them with various mildly acidic solutions, providing treatment with hot water or steam, freezing followed by maintanence lasting several days or weeks (Kasianenko, 2009) or instant freezing to form a glazed layer of ice (Kasianenko \& Gusjev, 2019). The use of peracetic acid and hydrogen peroxide drugs to improve the sanitary and hygienic condition of water in baths for cooling poultry carcasses after slaughter and to prevent crosscontamination of poultry carcasses with Campylobacter spp. was experimentally tested (Rodionova, 2017). It is crucial that the regimes of heat treatment of meat be followed at processing and culinary facilities (Kasianenko \& Gusjev, 2018).

At the level of poultry farms, especially medium and large ones, the risks of spreading Campylobacter spp. are significant, given the concentration of poultry in a limited area, intensive management, and the shortcomings of the monitoring system of campylobacteriosis in Ukraine (Kyryk, 2017). Factors that must be controlled on industrial farms to ensure the prevention of campylobacteriosis are as follows: vertical transmission of the pathogen, seasonality, farm staff, contamination of feed and water, insects, wild animals (including rodents) and synanthropic birds, livestock, contamination of the territory of poultry farm, the stocking density in the poultry house, air pollution in the poultry house, the presence of bacteria carriers in the poultry house, the number of poultry houses on the farm and the health of the poultry (Kasianenko \& Gusjev, 2019). Achieving the required sanitary condition is possible with the effective use of conventional disinfectants (Kasianenko \& Fotina, 2010; Pustovit \& Pinchuk, 2017), as complex disinfection significantly reduces the number of microbial cells in the air and on surfaces and equipment of poultry house, but disinfection as a targeted anti-epizootic measure in the prevention and elimination of infectious diseases is effective only in the context of a general set of measures, as control of all parts of the epizootic chain (Nechyporenko et al., 2018). At the same time, additional methods for controlling campylobacteriosis on poultry farms by treating poultry with antibacterial drugs (Kasianenko \& Sobyna, 2013) and probiotics in combination with adsorbents have been developed and proposed in Ukraine (Kasianenko, 2014). 


\section{Salmonellosis (Salmonella spp.)}

Salmonellosis is an animal and human disease with a fecal-oral transmission mechanism, manifesting as a lesion of the digestive system caused by pathogenic strains of Salmonella spp. Zoonotic non-typhoid pathogenic bacteria of the genus Salmonella, including S. cholerasuis and S. dublin, cause diarrhea in humans, whereas serotypes of S. typhimurium, S. enteritidis, S. newport, and S. heidelberg more often cause food poisoning (Yakubchak \& Kobysh, 2012; Chlebicz \& Śliżewska, 2018; Rukambile et al., 2019). According to EFSA and ECDC, salmonellosis is the second leading cause of intestinal infections in the European Union after campylobacteriosis and one of the leading causes of outbreaks of food poisoning. In 2018, 91,857 cases of the disease were reported in humans, and the intensity of the disease was 20.1 cases per 100,000 population. The highest levels of salmonella-positive samples were collected from poultry and other raw meat. Salmonella enteritidis was most often isolated during outbreaks of food poisoning by eggs and complex foods. Salmonella infantis was most commonly found in disadvantaged poultry flocks, namely $36.7 \%$ of all isolates, including $36.5 \%$ from broilers and $56.7 \%$ from broiler meat (EFSA, 2019).

According to the state institution "Center for Public Health of the Ministry of Health of Ukraine", salmonellosis is considered to be the main cause of infection-induced diarrhea and food poisoning in Ukraine. At the same time, 1-4 cases of typhoid and paratyphoid salmonellosis are reported per year, and other cases are caused by other (zoonotic) Salmonella serotypes. In 2018-2020, 3,621-7,452 such cases were registered annually, the intensity indicator was $8.62-19.3$ per 100,000 population, i.e. comparable to those in the European Union. According to the State Food and Consumer Service, in 2018 and 2019 in Ukraine five and six outbreaks of salmonellosis, respectively were confirmed on livestock farms, as well as 647,494 and 275,012 patients with salmonellosis of animal origin, mainly poultry. Poultry salmonellosis control programmes in Ukraine operated in 2009-2013, and now there is a valid normative document: instruction on the prevention and elimination of poultry salmonellosis, which contains clear science-based requirements for the implementation of salmonellosis control measures on poultry farms, including bacteriological control procedures. Sampling is carried out at all stages of rearing, slaughter and processing of poultry, as well as obtaining, sorting and distributing chicken eggs. Certainly, Salmonella can be found at some stages, which is the reason for the immediate use of precautionary measures against the spread of the pathogen, as well as its typification for establishing the level of its pathogenicity (Bojko et al., 2014).

In recent years, the epidemiological situation in Ukraine has remained tense. In 2010-2015, the incidence of salmonellosis in Ukraine was in the range of 18.5-22.1 per 100,000 population, without a tendency to decrease. The proportion of salmonellosis in the overall structure of acute intestinal infections (ACI) ranged from $8.1 \%$ to $10.3 \%$ (Malysh et al., 2016). The incidence differed in various regions of Ukraine: Kharkiv - average frequency is 53.4 , Khmelnytsky - 29.9, Cherkasy - 30.2 cases per 100,000 people. The lowest rates were observed in Kherson and Ternopil regions (average incidence of 8.4 and 4.7 per 100,000 population, respectively) (Doan \& Malysh, 2017). According to the results of the study from 2014-2015, there is a tendency to a higher manifestation of salmonellosis in the urban population rather than in the rural: $11.69-12.52$ cases per 100,000 population, including children under 17 with $34.14-37.26$ cases per 100,000 population. These cases were mainly related to food consumption rather than direct contact with sick people or animals (Zarytskyj et al., 2016; Ivakhno \& Kozyarin, 2019). Salmonella enteritidis and S. typhimurium predominate in the etiology of food salmonellosis in Ukraine. About $19.0-31.0 \%$ of such strains are detected annually (Neverkovets, 2011).

The incidence of salmonellosis in Ukraine is due to the constant inflow of Salmonella-contaminated raw meat, milk and eggs into the retail network. In general, in 2014-2018, the share of salmonellosis in the structure of outbreaks of acute intestinal infections ranged from $29.5 \%$ to $60.3 \%$. Most outbreaks of salmonellosis have occurred in public catering. At the same time, a significant number of them were associated with the infection of people at home, during various traditional events (weddings, funerals, memorial services, etc.), where a large number of dishes were prepared, probably in violation of sanitation rules. As the main causes of salmonellosis, the people affected listed the use of "questionable" (in terms of quality) food, including eggs and meat. In $89.6 \%$ of cases, outbreaks were caused by $S$. enteritidis, in $2.1 \%$ by $S$. typhimurium. S. blegdam and S. glostrup (strains which are relatively exotic in Ukraine) were the cause in $6.2 \%$ and in $2.1 \%$ of cases, respectively (Malysh, 2019); in the Ternopil region in 2009-2017 S. enteritidis was detected in 56.8-93.5\%, and S. typhimurium in $7.8-43.8 \%$ of cases. Exotic strains of salmonella not typical for the region were also found: S. soncord (in 2009), S. braenderup (in 2015), S. soncord and S. wippra (in 2009), S. give (in 2010), S. braenderup (in 2015), S. haifa (in 2016) (Pokryshko et al., 2017). In the Chernivtsi region in 2011-2015, patients were mainly diagnosed with S. enteritidis (325 cases) and S. typhimurium (37), rare types of Salmonella were detected in 12 cases (Moskalyuk et al., 2016). Salmonellosis is characterized by seasonality, an increase in the number of outbreaks of salmonellosis was observed in the warm season, mainly in July-August (Kozishkurt et al., 2019). The main factors in the transmission of non-typhoid salmonellosis are livestock products - meat, milk, eggs. Salmonella infection in animals is rarely diagnosed due to asymptomatic disease caused by host-adapted salmonella serovars. Therefore, the epidemic process of salmonellosis is associated with the dynamics of consumption of livestock products, rather than the dynamics of morbidity of animals and birds ( $\mathrm{Ga}-$ lushko, 2014).

Salmonellosis is now an extremely common disease among animals on industrial farms in Ukraine. Prevalence monitoring is mandatory and controlled by state authorities only in the case of poultry farms. According to studies conducted in Sumy region, $S$. enteritidis was isolated from the meat of forcibly slaughtered cattle in $8.8 \pm 0.8 \%$ of cases, whereas S. choleraesuis was detected in $14.7 \pm 0.7 \%$ of samples taken from the meat of slaughtered pigs. The frequency of isolation of $S$. typhimurium from pathological material of chickens reached $16.1 \%$, whereas for fur animals the rate was $12.8 \%$, for bees $-14.3 \%$, and for the meat of compulsory slaughtered cattle $-4.4 \%$ of the studied samples. A direct, strong relationship was confirmed between the frequency of isolation of S. typhimurium from pathological material of animals and the frequency of isolation of this pathogen from the clinical material of patients $(\mathrm{r}=0.89$; $\mathrm{m}_{\mathrm{r}}=0.10 ; \mathrm{t}=8.9$ ). That is, the activation of the epizootic process of this infection among animals entails a higher incidence of salmonellosis in the region (Malysh, 2019). The prevalence of Salmonella spp. cultures isolated from poultry determines the number and prevalence of salmonellosis outbreaks in humans, which are primarily related to the consumption of poultry products. Studies in Dnipropetrovsk region have established epizootiological patterns of salmonellosis in animals, namely: the leading role of poultry as a source of infection for poultry (S. gallinarum-pullorum, S. enteritidis) and humans (S. enteritidis) (Martynenko, 2019), such a situation was typical for most regions of Ukraine (Galka et al., 2019).

Salmonellosis in pigs and cattle has been reported in scientific studies less frequently than in the case of poultry. Salmonellosis was the second most common disease (after Escherichia coli) on Ukrainian pig farms in 1999-2013, and accounted for $13.3 \%$ of all confirmed cases of infectious diseases in pigs (Yakubchak et al., 2014). In the Poltava region in 2015, the share of salmonellosis in pigs was $35.1 \%$ of all documented diseases. All age groups of pigs, including $1.8 \%$ of fattening pigs, were infected on industrial farms. Such animals are especially dangerous to humans, as they are a source of infected meat (Melnyk \& Derevianko, 2015). Cases of salmonellosis in about 30-day-old calves have been detected on industrial farms and confirmed by serological methods when the disease was caused by $S$. dublin and S. typhimurium, and serological studies have indicated that calves were possible carriers of Salmonella (Pundjak, \& Kurtjak, 2013).

Circulation of Salmonella among pigs and cattle on farms inevitably leads to carcass contamination and a constant risk of salmonellosis. Research conducted in local markets of Mykolayiv established that $11.1 \%$ of carcasses of pigs and $9.1 \%$ of carcasses of cattle were contaminated with Salmonella of serovars of S. typhimurium (25.0\%), S. enteritidis (18.7\%), S. cholera suis (37.5\%) and S. paratyphi (18.7\%) (Brodovskyj \& Kovbasenko, 2016).

In recent years, a major problem has been the spread of antibioticresistant Salmonella strains on Ukrainian farms. A 1996-2005 study revealed the highest resistance of salmonella to sulfamethizole $(83.3 \%)$, 
cotrimoxazole $(75.0 \%)$, kanamycin $(58.3 \%)$ and tetracycline $(50.0 \%)$. In 2006-2012, the development of resistance to cefoxitin (73.2\%) and ceftriaxone $(42.3 \%)$, tetracycline $(31.5 \%)$ was observed (Bubalo, 2015). In 2016-2017, on poultry farms of Sumy region, Salmonella exhibited high resistance to amoxicillin, clindamycin, gentamicin, doxycycline, egocin and colistin (Klishhova, 2017). The proportion of antibiotic-resistant strains is constantly increasing, especially in the case of $\beta$-lactam antibiotics (cefazolin, ceftriaxone), aminoglycosides (gentamicin, streptomycin, kanamycin), tetracycline and polymyxin (Vygovska, 2018c; Chumachenko et al., 2019; Arefiev et al., 2020); poly-resistant strains appear (Rublenko \& Golovko, 2020). Antibiotic-resistant strains are spread in the environment, thus cultures of Salmonella isolated from wild birds were resistant to macrolides, benzylpenicillin and tetracyclines. This poses a threat to ecological systems and can lead to the emergence of reservoirs of resistant strains of Salmonella (Rula et al., 2019). Studies of egg yolk from wild migratory birds of different species in their nesting sites in the south of Ukraine reveal the presence of salmonella in an average of $17.0 \%$ of samples, mainly $S$. enteritidis, S. typhimurium, whereas isolated cultures were resistant to macrolide, penicillin and tetracyclines (Gljebova et al., 2014).

\section{Escherichiosis (E. coli including STEC)}

Escherichia coli is a Gram-negative, facultative anaerobic, rod-shaped bacterium of the Enterobacteriaceae family. Escherichia coli is one of the most common bacteria among normal non-pathogenic intestinal inhabitants of warm-blooded animals and Aves. However, strains of E. coli display an extremely large antigenic and morphological diversity. Some of the $E$. coli strains are an etiological factor of enterocolitis and diarrhea in animals and humans (diarrhoeal strains) (Malysh \& Chemych, 2015), other strains can cause various extra-intestinal diseases in humans (Salmanov et al., 2019). Strains of $E$. coli, which can cause diarrhea, are divided according to virulent and immunological properties, mechanisms of pathogenesis and the nature of symptoms of diseases that they cause. The following five groups of diarrhoeal strains of E. coli are commonly listed: enterotoxinogenic E. coli (ETEC), enteropathogenic E. coli (EPEC), enteroaggregative $E$. coli (EAggEC), enteroinvasive $E$. coli (EIEC) and Shiga (Vero) toxin-producing E. coli (STEC/VTEC) (Wasteson, 2001).

Currently, consolidated statistical reports on human E. coli in Ukraine are not publicly available, however, the analysis covering the period 2003-2013 indicates that the incidence of diarrhoeal $E$. coli can vary in the range of 1.7-5.4 per 100,000 population, while the etiological structure is dominated by enteroinvasive $E$. coli. There is a correlation between the prevalence of samples of milk and dairy products that do not meet sanitary and bacteriological indicators, and the incidence of escherichiosis caused by enteroinvasive $E$. coli. In addition, diarrheal escherichiosis was caused by EIEC $E$. coli in $33.6 \pm 2.1 \%$ of cases, including $29.4 \pm 1.9 \%$ cases associated with serogroup O1, i.e. the major cause of escherichiosis in poultry, wildfowl and decorative birds. In Sumy region, every third incident of diarrheal escherichiosis was caused by $E$. coli of the $\mathrm{O} 1$ serogroup (Malysh \& Chemych, 2015). At the same time, studies in Vinnytsa region have shown that colibacillosis accounts for an average of $35.9 \%$ of cases in the general infectious pathology of poultry of bacterial etiology, the disease is the most frequently observed in chickens (85.9\%) and has a seasonal character, with the greatest prevalence from April to September (86.2\% of all incidents) and morbidity rates peaking in August (20.0\%) (Melnyk \& Onyshchuk, 2015). Feed contaminated with mycotoxins is a contributing factor to the outbreak of colibacillosis in chickens (Ivchenko et al., 2018). In the industrial farming of turkeys, escherichiosis accounted for $78.6 \%$ of diseases of bacterial etiology. The etiological cause of colibacillosis was strains $E$. coli serovariants $\mathrm{O} 2, \mathrm{O} 78$ and $\mathrm{O} 111$. The intensity of the infectious process was associated with the level of total microbial contamination of aviaries, including the air inside (Bezvershenko et al., 2013).

During 2004-2015, E. coli was detected in 7.1\% of samples of pathological material collected from cattle, $7.3 \%$ from pigs, and $4.4 \%$ from poultry. Animal farms provide favourable conditions for the passage of pathogenic E. coli, which contributes to the spread of colibacillosis throu- ghout the country among all types of livestock (Vasilyeva, 2016). In 2011-2017 in Ukraine, the main pathogens in the infectious pathology of pigs of bacterial etiology were $E$. coli $-41.9 \%$ and the most frequently registered diseases were colibacillosis $-41.9 \%$ and cholieterotoxemia (edema) $-23.1 \%$ of all cases among confirmed diagnoses (Gorbatjuk et al., 2018; Zhovnir et al., 2019). Accessory factors for an increased prevalence of colibacillosis in piglets are high stocking density, characteristic of commercial pig farming, feeding defects that lead to hemodynamic disorders and changes in parenchymal organs and immunodeficiency states (Skrypka \& Zapeka, 2016).

The problem of antibiotic resistance of $E$. coli has been shown in studies in medicine and veterinary medicine (Borovyk, 2016). Polyantibioticresistant $E$. coli strains were found in isolates from clinically healthy $(49.2 \pm 9.8 \%)$ and sick $(87.2 \pm 5.4 \%)$ people (Voida, 2014). Antibiotic resistance of $E$. coli strains isolated from the surface of pig carcasses in Odesa region manifested itself in an average of $34.7 \%$ of cases, and in Sumy region in an average of $53.7 \%$ of cases. The greatest resistance of the isolate was to ampicillin - in $67.3 \%$ of isolates from Odesa region, and in $80.6 \%$ from Sumy region. In $45-47 \%$ of cases, resistant $E$. coli isolates exhibited monoresistance to antibiotics, while $32.0 \%$ of isolates were resistant to two antibiotics or more. Escherichia coli strains were resistant to ofloxacin in more than $95.0 \%$ of cases (Kasianchuk et al., 2018). Studies of antibiotic resistance of strains from the udder of cows with mastitis suggested that long presence of yeast cultures in the microbiocenosis together with $E$. coli cultures increases the antibiotic resistance of the latter (Kalashnikov, 2011), while in about $30.0 \%$ of cows with mastitis, E. coli was isolated from milk (Palii et al., 2020).

Though various $E$. coli serovariants are widespread and their etiological significance in human and animal diseases as well as the zoonotic potential of $E$. coli serovariants is inherent in various animal species, a major public health hazard and a generally recognized zoonotic $E$. coli is Shiga toxin-producing $E$. coli (STEC) (also known as verotoxigenic, verocytotoxigenic, verotoxin-producing, verocytotoxin-producing $E$. coli (VTEC)), in particular serotype O157:H7, spread worldwide, and serogroups O26, O103, O111, O145, which caused outbreaks in Europe (Wasteson, 2001). In 2018, the EU reported 8,161 confirmed cases of Shiga toxin-producing $E$. coli (STEC) infections in humans, accounting for 2.28 cases per 100,000 population, with a total of 48 outbreaks associated with contaminated $E$. coli food (milk, cheese, and mixed dishes, including plant-based foods) and five with contaminated water (EFSA, 2019). Currently, consolidated data on monitoring human colibacillosis caused by STEC and monitoring the prevalence of these serovariants among animals are not publicly available in Ukraine. Such information was not provided for by mandatory reporting in the health care system. However, since 2021, the updated legislation requires registering cases of human diseases caused by $E$. coli (with the exception of non-pathogenic strains) and E. coli, verocytotoxigenic strains (e.g. O157: $\mathrm{H} 7$ or O103) as separate items, as well as accumulating and analysing such information.

Currently, some difficulties in identifying STEC serotypes by bacteriological and immunological methods (Baluta et al., 2009; Sukharev, 2011) can be successfully solved using molecular genetic methods (Berhilevych et al., 2014, 2016, 2019; Kasianchuk et al., 2015). Molecular genetic studies have shown that STEC serovariates of $E$. coli can be collected from the carcasses of cattle and pigs. Between 2012 and 2015, 97 E. coli isolates $(42.2 \%)$ were isolated from 230 bacterial samples collected from flushes from beef (130) and swine (100) carcasses obtained from five slaughterhouses in Ukraine, among which seven (7.2\%) STEC strains (five beef and two swine carcass swabs) were identified by PCR (Berhilevych et al., 2018). In another study, Shiga toxin-producing $E$. coli (STEC) was detected in $8.1 \%$ and $5.7 \%$ of samples collected from beef and swine carcasses, respectively (Berhilevych et al., 2019). It indicates the extreme relevance of STEC monitoring at all stages of livestock production.

Previous scientific research suggests that STEC are common in Ukraine. STEC isolates were collected in $60.0 \%$ of unaffected farms, in $2.9-30.6 \%$ of cases from clinically healthy animals. In $29.4 \%$ of farms affected by diarrheal diseases of calves, STEC serotypes were detected in $12.9 \%$ of sick calves. STEC was also detected in $9.7 \%$ of piglets with diarrhea. Strains of $E$. coli serogroup O157 accounted for $2.0 \%$ of the total number of epizootic isolates of $E$. coli on Ukrainian farms, including $0.5 \%$ 
of the total number of $E$. coli crops isolated from cattle of different age groups and with different clinical status, and $1.5 \%$ of the total number of E. coli crops isolated from pigs (Zotsenko \& Volynets, 2002). The human and animal disease monitoring system for Shiga toxin-producing $E$. coli (STEC) and prevention of outbreaks of the disease needs to be improved, including strengthening monitoring of the spread of STEC among livestock.

\section{Listeriosis (Listeria spp.)}

The etiological factor of listeriosis in humans is the bacterium L. monocytogenes. Since the early 1980s, the pathogen has been associated with food poisoning. The genus Listeria includes 17 species of bacteria divided into two groups: Listeria sensu stricto, which includes L. monocytogenes, L. seelgeri, L. ivanovii, L. marthii, L. welshimeri, L. innocua, and Listeria sensu lato, which includes 11 more species divided into three genera. However, only L. monocytogenes is considered a zoonotic pathogen pathogenic to humans. Listeria monocytogenes is a Gram-positive bacterium, relatively aerobic, oxidase-negative and catalase-positive small mobile bacillus. The bacterium is able to grow in adverse temperature conditions $\left(-0.4\right.$ to $\left.45^{\circ} \mathrm{C}\right)$ and $\mathrm{pH}$ values (4.4-9.4), as well as in low humidity environments (Chlebicz \& Śliżewska, 2018).

In European Union countries, animals with listeriosis are an etiological factor in human listeriosis in $4.0 \%$ of cases; raw materials obtained from sick animals are the cause of contamination of food by pathogenic microorganisms in $38.0 \%$ of cases. In $45.0 \%$ of cases of human illness, food was the source of the pathogen (Machuskyi \& Kovtun, 2014). In Ukraine, 1-2 cases of listeriosis are officially registered annually, data on animal diseases are not officially accumulated. In 2018 in the EU there were 2,549 cases of listeriosis among people, with morbidity rate of 0.47 cases per 100,000 population and mortality rate of $15.6 \%$, making listeriosis one of the most serious foodborne diseases (EFSA, 2019).

In Ukraine, listeriosis is given insufficient attention in human and veterinary medicine (Randjuk et al., 2013). Human listeriosis is known as a serious threat to public health, manifested by severe meningitis and a high mortality rate (Pikul et al., 2011). Such clinical cases are described in Lviv region (Zinchuk et al., 2011) and Poltava region (Pikul et al., 2011). Listeriosis is a naturally occurring disease and the pathogen can survive for a long time in natural habitats, including populations of wild rodents and birds (Randjuk et al., 2013). Listeriosis is a saprozoonosis and characterized by a number of sources of infection, a variety of transmission routes, polymorphism of clinical manifestations and high mortality. Accordingly, it is possible to directly point to the basic difference between this infection and other food-borne zoonoses - listeriosis, like any saprozoonosis, is equally dangerous for both animals and humans. In soils of different geographical zones of Ukraine, depending on their use (in this case samples of soils used by the population for growing vegetables in-ground were the main subject of the study), Listeria was found in $18.7 \%$ of samples. Application of phosphorus and nitrogen fertilizers to the soil is the most conducive to the preservation and reproduction of listeria of different strains (Perotska, 2014).

In industrial livestock farming, cases of the spread of the listeriosis pathogen among the production livestock have been described. During 2011-2015, listeriosis infection was confirmed on livestock farms in the north-western region, as well as central and south-eastern parts of Ukraine. The highest incidence of listeriosis was found among small ruminants on farms in Zhytomyr region, with a tendency to increase from $50.0 \%$ of confirmed positive diagnoses in 2011 to $66.7 \%$ in 2015 . There is an upward trend of the incidence of listeriosis in cattle in Cherkasy region, as from $11.1 \%$ of confirmed positive results in 2011, these figures increased to $18.2 \%$ in 2015 and in pigs, respectively, from $13.2 \%$ of positive cases detected in 2011 to $14.3 \%$ in 2014 (Uhovska et al., 2017).

Laboratory diagnosis of Listeria spp. is imperfect, as the presence of other microflora and special conditions of cultivation and typing of the pathogen render the detection of the pathogen from food complicated (Borovyk \& Zazharska, 2019). Methods of laboratory diagnosis of listeriosis in Ukraine are improved by optimizing standard bacteriological methods of food testing (Kozhokaru et al., 2012), testing of meat of different species of animals (Bogatko, 2019), development of molecular genetic methods based on polymerase chain reaction (Ushkalov et al., 2014; Vyhovska, 2018d). The issue of antimicrobial resistance is also relevant for listeriosis. It was found that field isolates have a greater spectrum of antibiotic resistance than reference strains, and resistance differs in different field isolates (Vygovska, 2018a, 2018b).

\section{Manifestation features of food-borne bacterial zoonoses}

Zoonoses have a direct impact on public health in every country, Ukraine being no exception. For an outbreak of food-borne zoonosis, the following elements of the epidemic chain are necessary: the source of the pathogen - the routes of infection - susceptible organisms. This is true for any combination of elements from human and animal populations. The causative agents of common bacterial zoonoses in animals are either saprophytes (listeriosis) or have obligate hosts among animals (speciesspecific variants of $E$. coli, Salmonella, Campylobacter). In this case, these pathogens can also cause disease in humans (Lytvyn et al., 2002). The epidemiology of bacterial zoonoses includes several clusters: human population, animal population, environment. To a limited extent, pathogens of bacterial food-borne zoonoses can circulate in human populations, transmitted by contacts in a family or communal environment, involving permeating into food and causing outbreaks. However, this cannot be widespread given the very small number of latent carriers and the lack of social conditions for patients to come into contact with food (Bakhariev \& Nakonechnyi, 2019).

Bacterial pathogens also often contaminate food via slaughterhouses and processing plants with raw materials and food. For example, E. coli O1 serotypes, whose obligate hosts are considered to be chickens, often cause diarrhea in children in the Sumy region of Ukraine (Malysh \& Chemych, 2014). Mechanisms and risks of contamination of livestock products in slaughterhouses and processing plants are known and are mainly associated with violations of sanitary norms (Kasianenko \& Gusjev, 2019). Contamination of such factories can lead to contamination of large amounts of primary animal products by pathogenic bacteria, being a "bottleneck" in the food production chain.

In Ukraine, there is a noticeable gap between the medical and veterinary surveillance systems for bacterial zoonoses. The relationship between the circulation of bacterial zoonoses in humans and animals is difficult to grasp, but some authors point to facts that indicate that one exists (Fotina et al., 2014; Malysh et al., 2016). The underdiagnosis of campylobacteriosis cases in humans is obvious, given the prevalence of Campylobacter spp. in livestock, in particular broiler poultry, and the number of reported cases in humans and compared to the number of reported cases in humans in EU countries. There is no systematic monitoring of the spread of STEC in livestock, and the registration of human cases should begin in 2021. Human listeriosis is not always associated with animal products, although scientific studies indicate a significant prevalence of Listeria spp. not only in the environment, but also in industrial livestock farms. Avian salmonellosis seems to be the most controlled in Ukraine. In recent years, there have been special state programmes to control salmonellosis on poultry farms, and now such measures are enshrined in national legislation. At the same time, the role of pigs and cattle in outbreaks of salmonellosis in humans has not been studied sufficiently (Kyryk, 2013). Salmonellosis is the most commonly reported bacterial zoonosis in humans in Ukraine. The surveillance and response system for zoonotic bacterial pathogens requires a transformation based on the principles of the "One Health" approach.

\section{Potential role of industrial livestock farms in the spread of bacterial zoonoses}

Pathogens of food zoonoses are almost always microorganisms inherent in the fecal microflora of farm animals (Campylobacter, Salmonella, E. coli) or saprophytes, which are common on livestock farms (Listeria). Pathogenic strains of such bacteria also contaminate raw materials and food or the environment (water) and cause outbreaks of foodborne infections in humans. However, the onset among animals does not necessarily happen, because the animals may be carriers and show no symptoms of the disease. The peculiarity of such diseases is that the very presence of the 
pathogen in the animal's body is a necessary but insufficient condition for the development of the disease; such diseases are called "factor" (Lytvyn et al., 2002). A sufficient set of factors for the development of the disease is formed due to the peculiarities of the technologies of industrial keeping of animals. Factors caused by the very concept of an industrial livestock farm are always present: the concentration of a large number of animals on one farm, the same standardized feeding, limited territory, the contacts of livestock with technological processes and personnel, the focus on reaching the highest productivity, economic feasibility of technologies for keeping animals. Factors that occur on industrial farms in case of technological defects or violations of sanitation, feeding, keeping and transportation conditions, etc.: inadequate hygienic conditions which reduce the resistance of animals, excess microbial contamination in the farms' environment, long-term feeding violations affecting the whole herd, age groups mixture and introduction of new animals into the herd without quarantine (import of pathogens), joint or close keeping different animal species together or nearby, uncontrolled widespread use of antibiotics. Industrial livestock farms affect the ecology of the environment: excessive pressure on ecosystems due to the production of large amounts of feces, pollution of water resources, the formation of antimicrobial resistance in the microflora of habitats. Outbreaks of factor bacterial zoonotic diseases on industrial livestock farms are highly likely, given the presence of all necessary (pathogens) and sufficient (factors) elements and the apparently low resistance of farmed animals. Therefore, industrial livestock farms are an important potential source of bacterial zoonoses for humans (Fig. 4).

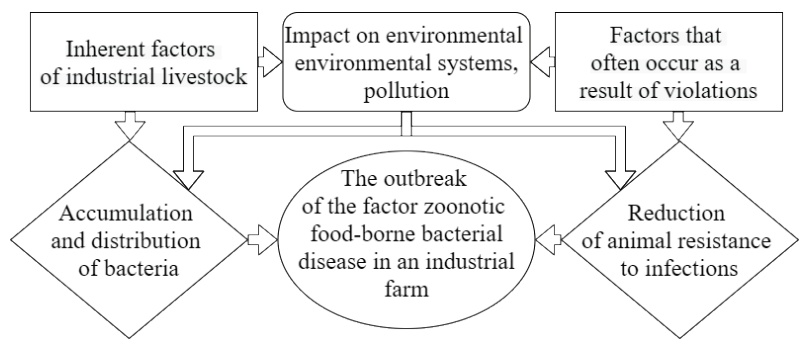

Fig. 4. Scheme of outbreak of factor zoonotic bacterial disease on an industrial farm

A combination of favourable factors for the accumulation and passage of pathogens of bacterial diseases and animal immunological insufficiency, acquired as a result of industrial farming, contributes to outbreaks of factor bacterial diseases (Skrypka \& Zapeka, 2016) and significantly increases the risk of the pathogen entering livestock products and the environment.

\section{Conclusions}

The system of state supervision over the main food zoonoses (campylobacteriosis, salmonellosis, STEC, listeriosis) is characterized by an imbalance of medical and veterinary components. Ukraine has the highest number of confirmed cases of salmonellosis in humans and poultry. The system of notification and surveillance of other bacterial zoonoses is not organized effectively enough, although scientific studies indicate their significant spread among humans and animals. In Ukraine, the practice of industrial farming is widespread. Depending on the species, $30-60 \%$ of animals are kept on industrial farms, more than half of farms can be classified as medium and large. Industrial technology actively affects the health status of animals, and in the event of a violation of technology, the risk of factor diseases increases dramatically and the risk of spreading their pathogens along with livestock products increases. For each of the studied pathogens, scientific research highlights the problem of antimicrobial resistance. The general trend for bacterial zoonoses is expanding the resistance spectrum of strains isolated from sick people, animals and the environment on livestock farms. The potential role of industrial livestock farms in the spread of bacterial zoonoses can be identified as important and in need of further study.

The work is supported by a grant from Tiny Beam Fund (Award 2020, No. 11). All statements, advice or opinions expressed in it are solely those of its authors. The authors thank Stowarzyszenie "Otwarte Klatki” ("Open Cages" Association).
The authors declare no competing interests.

\section{References}

Andrukh, V. S. (2015). Hostri hastroenteryty v ditei: Shcho novoho [Acute gastroenteritis in children: What's new]. Praktykuyuchyj Likar, 2, 36-37 (in Ukrainian).

Antunes, P., Novais, C., \& Peixe, L. (2019). Food-to-humans bacterial transmission. Microbial Transmission, 8(1), 161-193.

Arefiev, V., Kovalenko, G., Frant, M., Chumachenko, T., Polyvianna, Y., Pivnenko, S., \& Drown, D. M. (2020). Complete genome sequence of Salmonella enterica subsp. enterica serovar Kottbus strain Kharkiv, isolated from a commercial pork production facility in Ukraine. Microbiology Resource Announcements, 9(49), 7-9.

Babkin, A. F., \& Kalinichenko, T. V. (2010). Suchasni aspekty diahnostyky kampilobakterioziv [Modern aspects of diagnosis of campylobacteriosis]. Veterynama Medytsyna, 93, 9-15 (in Ukrainian).

Babkin, A. F., Obukhovska, O. V., Kutsenko, V. A., \& Kalinichenko, T. V. (2013). Vyvchennia biolohichnykh vlastyvostej polovykh izoliativ i muzejnykh shtamiv kampilobakterij [Study of biological properties of Campylobacter field isolates and museum strains]. Veterynarna Medytsyna, 97, 57-60 (in Ukrainian).

Baharev, Y., \& Nakonechno, I. (2019). Ekoloho-epidemichni aspekty zoohennykh rezervuariv i dzherel salmonel u Pivnichno-Zakhidnomu Prychomomoryi [Ecological and epidemic aspects of zoogenic reservoirs and salmonella sources in the Northwest Black Sea region]. Logos, 7, 50-58 (in Ukrainian).

Baluta, I. M., Malanchuk, S. G., Golubka, O. V., Mizin, V. V., Bondar, V. O., \& Alhusin, M. A. (2009). Deiaki problemy mikrobiolohichnoji diahnostyky esherykhiozu i kolibakteriozu v humannij ta veterynamij medytsyni [Some problems of microbiological diagnosis of echerichiosis and colibacteriosis in human and veterinary medicine]. Annals of Mechnikov Institute, 3, 30-32 (in Ukrainian).

Bergylevich, O. M., Kasyanchuk, V. V., Deryabin, O. M., Efimova, O. M., \& Kusturov, V. B. (2016). Rozrobka olihonukleotydnykh praimeriv, spetsyfichnykh do heniv shyhatoksynu stx 1 , stx 2 ta intyminu eae shyhatoksynprodukuiuchykh E. coli [Development of oligonucleotide primers specific to the shigaetoxin genes stx 1, stx 2 and intimin eae shigatoxin products of $E$. coli]. Problems of Zoengineering and Veterinary Medicine, 33(2), 154-160 (in Ukrainian).

Berhilevych, O., Pylypenko, L., Kasianchuk, V., Ilyeva, A., \& Shubin, P. (2019). Identification of food pathogens and determination of their distribution level in Ukrainian food products of animal and plant origin by PCR method. Food Science and Technology, 13(4), 76-86.

Berhilevych, O. M., Kasianchuk, V. V., \& Yefimova, O. M. (2014). Markery patohennosti $E$. coli $\mathrm{O} 157: \mathrm{H} 7$ ta osnovni heny-misheni dlia diahnostyky tsoho mikroorhanizmu v yalovychyni test-systemoiu PLR [Markers of pathogenicity E. coli $\mathrm{O} 157: \mathrm{H} 7$ and basic target genes for diagnostics of this microorganism in beef Test-system PCR]. Problems of Zoengineering and Veterinary Medicine, 29(2), 188-191 (in Ukrainian).

Berthe, F., Hugas, M., \& Makela, P. (2013). Integrating surveillance of animal health, food pathogens and foodborne disease in the European Union. Revue Scientifique et Technique de l'OIE, 32(2), 521-528.

Bezvershenko, O. S., Zon, G. A., \& Kuprijenko, L. S. (2013). Rezuljtaty vyvchennja epizootychnoji sytuaciji shhodo esherykhiozu pry promyslovomu utrymanni indykiv [Results of examination of the epizootic situation with regard to echerichiosis in industrial maintenance of turkeys]. Veterynama Medycyna, 97, 157160.

Bogatko, N. (2019). Listeria monocytogenes - microbiological criteria indicate the acceptability of safety meat raws. The Animal Biology, 21(2), 85.

Bojko, P., Kurtjak, B., Senj, O., Pundjak, T., \& Sobko, G. (2014). Osoblyvosti kontrolju epizootychnogho procesu za saljmoneljozu ptyci u ptakhivnychykh ghospodarstvkh Ukrajiny [Features of control of the epizootic process for poultry salmonellosis on poultry farms of Ukraine]. Naukovyj Visnyk LNUVMBT imeni S. Z. Ghzhyckogho, 60, 59-64.

Borovyk, I. V. (2016). Monitoryng chutlyvosti mikroorganizmiv do antybakterial'nyh preparativ u Dnipropetrovs'kij oblasti [Monitoring of the sensitivity of microorganisms to antibacterial drugs in Dnipropetrovsk region]. Problemy Zooinzheneriji ta Veterynamoji Medycyny, 33(2), 79-82.

Borovyk, I. V., \& Zazharska, N. M. (2019). Osoblyvosti laboratornoji diahnostyky Listeria spp. [Particularities of laboratory diagnostics of Listeria spp.]. Theoretical and Applied Veterinary Medicine, 7(4), 236-244 (in Ukrainian).

Brodovskyj, V. A., \& Kovbasenko, V. M. (2016). Obsimeninnja sal'monelamy jalovychyny i svynyny, jaki nadhodjat' v realizaciju z prysadybnyh i fermers'kyh gospodarstv [Salmonella contamination of beef and pork which occur in gardens and farms]. Scientific Messenger of Lviv National University of Veterinary Medicine and Biotechnologies, Series Veterinary Sciences, 71, 15-18 (in Ukrainian).

Bubalo, V. O. (2015). Sensitivity to antibiotics among strains of Salmonella current, which circulates in the past 10 years in Ukraine. The Journal of V. N. Karazin Kharkiv National University, Series Medicine, 26,9-16. 
Casey, J. A., Kim, B. F., Larsen, J., Price, L. B., \& Nachman, K. E. (2015). Industrial food animal production and community health. Current Environmental Health Reports, 2(3), 259-271.

Chlebicz, A., \& Śliżewska, K. (2018). Campylobacteriosis, salmonellosis, yersiniosis, and listeriosis as zoonotic foodborne diseases: A review. International Journal of Environmental Research and Public Health, 15(5), 863.

Chumachenko, T., Karlova, T., Pivnenko, S., \& Makhota, L. (2019). Prevalence of antimicrobial resistance in Salmonella spp. strains isolated from human in Kharkiv Region, Ukraine. International Journal of Infectious Diseases, 79, 45.

Cutler, S. J. (2015). Bacterial zoonoses: An overview. In: Редактор(а). Molecular Medical Microbiology. Academic Press, Город(a). Pp. 1771-1780.

Doan, S. I., \& Malysh, N. G. (2017). Epidemiological features of diarrheal infections in Ukraine. Actual Infectology, 5(4), 172-176.

Drahut, S. S. (2013). Rozpovsjudzhennja sal'monel'ozu, kampilobakteriozu ta ijersyniozu v Ukrajini ta krajinah JeS [Distrbution of salmonellosis, campylobacteriosis and yersiniosis in Ukraine and EU countries]. Veterinary Medicine, 97, 186-188 (in Ukrainian)

EFSA and ECDC (European Food Safety Authority and European Centre for Disease Prevention and Control). (2019). The European Union one health 2018 zoonoses report. EFSA Journal, 17(12), 5926.

Facciolà, A., Riso, R., Avventuroso, E., Visalli, G., Delia, S. A., \& Laganà, P. (2017) Campylobacter: From microbiology to prevention. Journal of Preventive Medicine and Hygiene, 58(2), E79-E92.

Fotina, T. I., Fotina, G. A., Klishhova, Z. E., Arefjeva, V. L., \& Chemych, O. M (2018). Rol' monitoryngu ta kontrolju za toksykoinfekcijamy ta toksykozamy u zabezpechenni biobezpeky naselennia Ukrajiny [The role of monitoring and control over toxico infections and toxicosis in ensuring biosafety of the population of Ukraine]. Veterynarna Biotehnologija, 32(2), 585-592 (in Ukrainian).

Fotina, T. I., Kasjanenko, O. I., Fotina, G. A., \& Dvors'ka, J. E. (2014). Epizootologichne ta epidemiologichni znachennia harchovyh bakterial'nyh patogeniv [Epizootological and epidemiological values of food bacterial pathogens]. The Animal Biology, 2-3, 141-148 (in Ukrainian).

Galka, I. V., Muzykina, L. M., Mandygra, S. S., Chehun, A. I., \& Sydorenko, T. V. (2019). Poshyrennja sal'monel'ozu tvaryn ta ptyci y Ukrajini u 2015-2018 rokah [Distribution of salmonellosis of animals and poultry and Ukraine in 20152018]. Veterynarna Biotehnologija, 35, 22-29 (in Ukrainian).

Galushko, A. V. (2014). Osoblyvosti epidemichnogo procesu netyfojidnyh sal'monel'oziv v Ukrajini [Features of the epidemic process of non-type salmonellosis in Ukraine]. In: Pogorjelov, M. V. (Ed.). Aktual'ni pytannja teoretychnoji ta praktychnoji medycyny. SumDU, Sumy. Pp. 231-232 (in Ukrainian).

Gljebova, K. V., \& Bobrovycka, I. A., \& Majboroda, O. V. (2014). Monitoryng sal'monel'ozu dykoji ptyci pivdnja Ukrajiny [Monitoring of salmonelliosis of wild birds in the south of Ukraine]. Veterynama Medycyna, 99, 83-86 (in Ukrainian).

Gorbatjuk, O. I., Uhovs'ka, T. M., Tjutjun, S. M., Andrijashhuk, V. O., Ryzhenko, G. F., \& Zhovnir, O. M. (2018). Bakteriologichnyj monitoryng infekcijnyh zahvorjuvan' svynej ta zasoby jih specyfichnoji profilaktyky [Bacteriological monitoring of infectious diseases of pigs and means of their specific prophylaxis]. Veterynarna Biotehnologija, 33, 3-15 (in Ukrainian)

Gupta, S., Rajiah, P., Middlebrooks, E. H., Baruah, D., Carter, B. W., Burton, K. R. \& Miller, M. M. (2018). Systematic review of the literature: Best practices. Academic Radiology, 25(11), 1481-1490.

Hallaj, Z. (2010). Global trends in emerging zoonoses. International Journal of Antimicrobial Agents, 36(1), 1-2.

Ivakhno, A. P., \& Kozyarin, I. P. (2019). Suchasnyj stan zakhvoriuvanosti ditej na salmonelozy v Ukrajini [Current status of prevalence of salmonellosis among children in Ukraine]. Environment and Health, 92, 23-27 (in Ukrainian).

Ivchenko, V. M., Papchenko, I. V., Levkivska, N. D., \& Levkivskyy, D. M. (2018) Kolibakterioz kurchat ta zakhody profilaktyky [Colibacillosis in chickens and prophylaxis methods]. Scientific Messenger of LNU of Veterinary Medicine and Biotechnologies, 88, 89-93 (in Ukrainian).

Kalashnikov, V. O. (2011). Chutlyvist' mikrobnyh asociacij riznogo skladu do antybiotykiv na prykladi Escherichia coli ta Candida albicans, vydilenyh iz moloka koriv [Sensitivity of microbial associations of various composition to antibiotics on example Escherichia coli and Candida albicans isolated from cows milk]. The Animal Biology, 13, 455-458 (in Ukrainian).

Kasianchuk, V. V., Berhilevych, O. M., Kusturov, V. B., \& Deriabin, O. M. (2018) Rezystentnist izoliativ Escherichia coli, vydilenykh z poverkhni tush svynej do antybakterialnykh preparativ [Resistance of Escherichia coli isolates isolated from the surface of the carcasses of pigs to antibacterial preparations]. Veterinary Biotechnology, 32(2), 219-229 (in Ukrainian).

Kasianchuk, V. V., Ushkalov, V. O., Berhilevych, O. M., Deriabin, O. M., Yefimova, O. M., \& Kozii, R. V. (2015). Vyjavlennja ta identyfikaciji shygatoksyn produkujuchyh shtamiv bakterij $E$. coli metodom polimeraznoji lancjugovoji reakciji [Detection and identification of shigatoxin of producing strains of bacteria E. coli by polymerase chain reaction method]. Bulletin of Sumy National Agrarian University, Veterinary Medicine Series, 37, 121-125 (in Ukrainian).

Kasianenko, O. I. (2009). Vplyv oholodzhennia ta zamorozhuvannia mjasa na stijkist' zbudnyka kampilobakteriozu [Influence of cooling and freezing of meat on the stability of the campylobacteriosis pathogen]. Scientific Messenger of Lviv National University of Veterinary Medicine and Biotechnologies, Series Veterinary Sciences, $41,80-83$ (in Ukrainian).

Kasianenko, O. I. (2012). Epizootychnyj monitoryng poshyrennja Campylobacter spp. sered ptyci v umovah zabijnyh cehiv Ukrajiny [Epizootic monitoring of Campylobacter spp. among birds in the conditions of slaughterhouses in Ukraine]. Bulletin of Sumy National Agrarian University, Veterinary Medicine Series, 31(7), 114-118 (in Ukrainian).

Kasianenko, O. I., \& Fotina, T. I. (2010). Chutlyvist' mikroorganizmiv Campylobacter spp. do dezinfektantiv [Sensitivity of microorganisms Campylobacter spp. to disinfectants]. Veterinary Medicine, 93, 197-201 (in Ukrainian).

Kasianenko, O. I., \& Gusjev, V. O. (2018). Znezarazhennja m'jasa ptyci za kontaminaciji Campylobacter spp. [Disinfection of poultry meat from contamination of Campylobacter spp.]. The Animal Biology, 20(4), 109 (in Ukrainian).

Kasianenko, O. I., \& Gusjev, V. O. (2019). Sposoby znyzhennja rivnja bakterial'noji kontaminaciji tushok ptyci [Methods of reducing the level of bacterial contamination of poultry carcasses]. Bulletin of Sumy National Agrarian University, Veterinary Medicine Series, 46, 41-47 (in Ukrainian).

Kasianenko, O. I., \& Sobyna, M. M. (2013). Eksperymental'ne ta praktychne obgruntuvannja efektyvnosti zastosuvnnja preparatu "Bi-septym" v systemi profilaktychnyh zahodiv kampilobakterioznoji infekciji ptyci [Experimental and practical substantiation of the effectiveness of the drug "Bi-Septim" in the system of preventive measures of campylobacteriosis poultry infection]. Veterinary Biotechnology, 22, 181-187 (in Ukrainian).

Kasianenko, O. I., Fotyna, T. Y., Fotyna, A. A., Gladchenko, S. M., Gnydenko, T. J., \& Bezruk, R. V. (2017). Svojstva shtammov Campylobacter jejuni, izolirovannyh iz produktov ptycevodstva [Properties of Campylobacter jejuni that were isolated from poultry products]. Mikrobiologicheskij Zhurnal, 79(4), 66-74 (in Russian).

Kasianenko, O. I., Gusjev, V. O., Kasianenko, S., Nahorna, L. V., \& Punko, I. V. (2019). Vyznachennja rivnja infikuvannja zabijnoji ptyci mikroorganizmamy Campylobacter spp. [Determination of the level of infection of slaughter poultry microorganisms Campylobacter spp.]. Veterinary Biotechnology, 34, 59-66 (in Ukrainian).

Kasianenko, O. I., Sobyna, M. M., \& Gladchenko, S. M. (2014). Rozrobka al'ternatyvnyh zasobiv profilaktyky kampilobakterioznoji infekciji ptyci [Development of alternative means of prevention of campylobacteriosis poultry infection]. Scientific Messenger of Lviv National University of Veterinary Medicine and Biotechnologies, Series Veterinary Sciences, 3(1), 131-137 (in Ukrainian).

Klishhova, Z. J. (2017). Vyznachennja rezystentnosti vydilenyh zbudnykiv sal'monel'ozu ta esheryhiozu do antybakterial'nyh preparativ [Detection of resistance of allocated agents of salmonellosis and escherichiosis to antibacterial drugs]. Bulletin of Sumy National Agrarian University, Veterinary Medicine Series, 40, 91-95 (in Ukrainian).

Kozhokaru, A. A., Skoropad, V. I., \& Ivanko, O. M. (2012). Zahody profilaktyky listeriozu ta udoskonalennja metodu doslidzhennja harchovoji produkciji na prysutnist' Listeria monocytogenes [Measures for the prevention of listeriosis and improvement of the method of researching food products on the presence of Listeria monocytogenes]. Problemy Vijs'kovoji Ohorony Zdorov'ja, 33, 124-131 (in Ukrainian).

Kozishkurt, O. V., Golubjatnykov, M. I., Doan, S. I., Mogylevs'kyj, L. J., Tymoshenko, O. M., \& Jeremjejeva, N. V. (2019). Kyshkovi infekciji bakterial'noji pryrody: Epidemichna sytuacija na pivdni Ukrajiny [Intestinal infections of bacterial nature: Epidemic situation in Southern Ukraine]. Visnyk Mors'koji Medycyny, 85(4), 79-89.

Kyryk, D. L. (2011). Harakterystyka dejakyh biologichnyh vlastyvostej kampilobakterij riznogo pohodzhennja ta jih vplyv na epidemichnyj proces kampilobakteriozu [Characteristics of some biological properties of campylobacteria of various origins and their influence on the epidemic process of campylobacteriosis] Ukrajins'kyj Medychnyj Chasopys, 2, 111-113 (in Ukrainian).

Kyryk, D. L. (2012a). Biologichni vlastyvosti bakterij rodu Campylobacter ta jih vplyv na epidemichnyj proces kampilobakteriozu [Biological properties of the bacteria of the genus Campylobacter and their influence on the epidemic process of campylobacteriosis]. Profilaktychna Medycyna, 19, 82-88 (in Ukrainian).

Kyryk, D. L. (2012b). Harakterystyka epidemichnogo procesu kampilobakteriozu ta epidemiologichne markuvannia shtamiv kampilobakterij riznogo pohodzhennia [Characteristics of the epidemic process of campylobacteriosis and epidemiological marking of campylobacteria strains of different origin]. Ukrajins'kyj Medychnyj Chasopys, 3, 100-103 (in Ukrainian)

Kyryk, D. L. (2013). Kliniko-epidemiologichni osoblyvosti kampilobakteriozu v Ukrajini [Clinical and epidemiological features of campylobacteriosis in Ukraine]. Ukrajins'kyj Medychnyj Chasopys, 95(3), 162-164 (in Ukrainian).

Kyryk, D. L. (2016). Mikrobiologichna diagnostyka kampilobakterioznoji infekciji [Microbiological diagnostics of campylobacteriosis infection]. Medychna Osvita, 26, 579-587 (in Ukrainian).

Kyryk, D. L. (2017). Organizacija kompleksnogo epidemiologichnogo nagljadu za kampilobakteriozom v suchasnyh umovah [Organization of integrated epide- 
miological supervision of campylobacteriosis in modern conditions]. Vlachebnoe Delo, 1-2, 120-124 (in Ukrainian)

Lapa, O. I., Yakubchak, O. M., \& Zahrebelnyj, V. O. (2015). Shhodo osoblyvostej vydilennja kampilobakterij [Regarding the features of allocation of campylobacteria]. Scientific reports of the National University of Life and Environmental Sciences of Ukraine, Veterinary Medicine, Quality and Safety of Livestock Products, 22(1), 229-233 (in Ukrainian).

Lavruk, O. V., \& Lavruk, N. A. (2020). Tvarynnytstvo: Stan ta perspektyvy rozvytku [Livestock: State and development prospects]. Agrosvit, 22,9 (in Ukrainian).

Lytvyn, V. P., Oliinyk, L. V., Korniienko, L. E., Yarchuk, B. M., Dombrovskyi, O. B., \& Korniienko, L. M. (2002). Faktorni hvoroby sil's'kogospodars'kyh tvaryn [Factors deseases of farm animals]. Bilotserkivskyj NAU, Bila Tserkva (in Ukrainian).

Machuskyi, O. V., \& Kovtun, V. A. (2014). Listerioz. Epizootologichna ta epidemiologichna sytuacija na prykladi derzhav Jevropejs'kogo sojuzu [Listeriosis. Epizootological and epidemiological situation on the example of the countries of the European Union]. Bulletin of Sumy National Agrarian University, Veterinary Medicine Series, 34, 149-154 (in Ukrainian).

Malysh, N. H. (2019). Sal'monel'oz v Ukrajini: Epidemiologichni aspekty [Salmonellosis in Ukraine: Epidemiological aspects]. In: Ngujen, I. V. (Ed.). Materialy Naukovo-Praktychnoji Konferenciji z Mizhnarodnoju Uchastju, Prysvjachenoji Shhorichnym “Chytannjam” Pamjati Akademika L. V. Gromashevs'kogo. Instytut Epidemiologii ta Infekcijnyh Hvorob imeni L. V. Gromashevs'kogo, Kyiv. Pp. 116-119 (in Ukrainian).

Malysh, N. H., \& Chemych, M. D. (2015). Diarejegenni esheryhiozy: Zahvorjuvanist', etiologichnyj pejzazh, faktory ryzyku [Diarnheagenic escherichiosis: Incidence, etiologic structure, factors of risk]. Infektsiini Khvoroby, 3, 76-78 (in Ukrainian).

Malysh, N. H., Zaryc'kyj, A. M., \& Glushkevych, T. G. (2016). Sal'monel'ozy v Ukrajini: Problemni pytannja epidemiologichnogo nagljadu [Salmonellas in Ukraine: Problematic issues of epidemiological supervision]. Profilaktychna Medycyna, 1(2), 33-40 (in Ukrainian).

Martynenko, H. A. (2019). Analiz ta prohnozuvannia antybiotykorezystentnost Salmonella spp. u Dnipropetrovskij oblasti (Ukraina) [Analysis and forecasts of Salmonella spp. antibiotic resistance in Dnipropetrovsk region (Ukraine)]. Veterinary Medicine, 105, 16-19 (in Ukrainian).

Melnyk, V. V., \& Derevianko, I. J. (2015). Epizootologichni osoblyvosti sal'monel'ozu svynej v Poltavs'kij oblasti [Epizootological features of salmonelliosis of pigs in the Poltava region]. Naukovo-Tehnichnyj Bjuleten NDC Biobezpeky ta Ekologichnogo Kontrolju Resursiv APK, 3(2), 61-66 (in Ukrainian).

Melnyk, V. V., \& Onyshchuk, A. V. (2015). Epizootologichni osoblyvosti kolibakteriozu ptyci u Vinnyc'kij oblasti [Epizootological features of colibacteriosis of poultry in Vinnytsia region]. Naukovo-Tehnichnyj Bjuleten NDC Biobezpeky ta Ekologichnogo Kontrolju Resursiv APK, 3(1), 75-77 (in Ukrainian).

Morwal, S. (2017). Bacterial zoonosis - a public health importance. Journal of Dairy, Veterinary and Animal Research, 5(2), 56-59.

Nechyporenko, O. L., Berezovs'kyj, A. V., Fotina, T. I., Petrov, R. V., \& Fotin, A. I. (2018). Efektyvnist' kompleksnyh dezinfikujuchyh zahodiv v umovah ptahogospodarstva [Effectiveness of complex disinfectant measures in poultry farm] Scientific Messenger of Lviv National University of Veterinary Medicine and Biotechnologies, Series Veterinary Sciences, 92, 165-168 (in Ukrainian).

Neverkovets, N. J. (2011). Analiz etiologichnogo znachennja sal'monel sered inshyh zbudnykiv harchovyh toksykoinfekcij v Ukrajini [Analysis of the etiological value of Salmonella among other pathogens of food toxicoinfections in Ukraine]. Veterinary Medicine, 95, 255-257 (in Ukrainian).

Palii, A. P., Kovalchuk, Y. O., \& Grebnova, I. V. (2020). Species composition of microbiota of cows udder and raw milk quality at mastitis. Ukrainian Journal of Ecology, 10(4), 78-85.

Perotska, L. V. (2014). Strukturno-funkcional'na organizacija chynnykiv, sho inicijujut' enzootychnyj proces (na prykladi listeriozu) [Structural-functional organization of factors that initiate the enzootic process (on the example of listeriosis)] Agrarnyj Visnyk Prychornomorja, 72, 57-61 (in Ukrainian).

Pidpala, T. V., Jasevin, S. J., \& Marykina, O. S. (2018). Intensyvni tehnologiji u molochnomu skotarstvi [Intense technologies in dairy cattle breeding]. Mykolaiv National Agrarian University, Mykolaiv (in Ukrainian).

Pikul, K. V., Pryluc'kyj, K. J., Sosnovs'ka, N. M., Poltorapavlov, V. A., \& Il'chenko, V. I. (2011). Nevidomyj listerioz iz storichnoju istorijeju vyvchennja [Unknown listeriosis with a century history of study]. Svit Medycyny ta Biologiji, 3, 155159 (in Ukrainian).

Pinchuk, N. G., \& Pustovit, N. A. (2018). Kampilobakterioz jak vazhlyva harchova toksykoinfekcija [Campylobacteriosis as an important food toxicoinfection] Bulletin of the Poltava State Agrarian Academy, 2, 136-140 (in Ukrainian).

Pokryshko, O. V., Barna, T. B., \& Klymnyuk, S. I. (2017). Identification of Salmonella serovars isolated during 2009-2016 in Ternopil region, Ukraine. Annals of Mechnikov Institute, 2, 45-46.

Pundjak, T. O., \& Kurtjak, B. M. (2013). Dynamika tytriv antytil za spontannogo sal'monel'ozu u teljat [Dynamics of antibody titers for spontaneous salmonellosis in calves]. The Animal Biology, 15(4), 106-111 (in Ukrainian).
Pustovit, N. A., \& Pinchuk, N. H. (2017). Doslidzhennia vplyvu promyslovyh dezinfikujuchyh zasobiv na stijkist' izoliativ vydilenyh vid ptyci [Investigation of the influence of industrial disinfectants on the stability of isolates isolated from poultry]. Veterinary Medicine, 103, 142-146 (in Ukrainian).

Randjuk, J. O., Moskaljuk, V. D., Sokol, A. M., \& Sydorchuk, A. S. (2013). Listeriozmalovidoma oportunistychna infekcija [Listeriosis-little-known opportunistic infection]. Bukovyns'kyj Medychnyj Visnyk, 66, 161-167 (in Ukrainian).

Rodionova, K. O. (2017). Kontrol' mikrobiologichnoji bezpeky (Campylobacter spp.) tushok ptyci v procesi jih pererobky [Control of microbiological safety (Campylobacter spp.) poultry carcasses in the process of their processing]. Bulletin of the Poltava State Agrarian Academy, 3, 137-139 (in Ukrainian).

Rublenko, N. M., \& Golovko, A. M. (2020). Chutlyvist' do antybakterialnykh preparativ u izoliativ Salmonella enterica subsp. enterica, vydilenykh na terytoriji Ukrajiny v 2014-2017 rr. [Antimicrobial susceptibility of isolates of Salmonella enterica subsp. enterica isolated in Ukraine during the period of 2014-2017]. Scientific Messenger of LNU of Veterinary Medicine and Biotechnologies, Series Veterinary Sciences, 22(97), 58-68 (in Ukrainian)

Rukambile, E., Sintchenko, V., Muscatello, G., Kock, R., \& Alders, R. (2019). Infection, colonization and shedding of Campylobacter and Salmonella in animals and their contribution to human disease: A review. Zoonoses and Public Health, $66(6), 562-578$

Rula, O., Maiboroda, O., Kryvoshei, Y., Gerashchenko, N., Muzyka, D., \& Stegniy, B. T. (2019). Monitoring for the circulation of antibiotic-resistant Salmonella in poultry and wild birds in Ukraine in 2017. International Journal of Infectious Diseases, 71(9), 42.

Salmanov, A., Vozianov, S., Kryzhevsky, V., Litus, O., Drozdova, A., \& Vlasenko, I. (2019). Prevalence of healthcare-associated infections and antimicrobial resistance in acute care hospitals in Kyiv, Ukraine. Journal of Hospital Infection, $102(4), 431-437$

Schiaffino, F., Platts-Mills, J., \& Kosek, M. N. (2019). A one health approach to prevention, treatment, and control of campylobacteriosis. Current Opinion in Infectious Diseases, 32(5), 453-460.

Skrypka, M. V., \& Zapeka, I. J. (2016). Patomorfologichni zminy v organizmi porosiat $\mathrm{v}$ prodromal'nyj period kolibakteriozu [Pathomorphological changes in the organism of piglets in the prodromal period of colibacteriosis]. Scientific Reports of the National University of Life and Environmental Sciences of Ukraine, Veterinary Medicine, Quality and Safety of Livestock Products, 237 328-336 (in Ukrainian).

State Statistics Service of Ukraine (2019). Silske hospodarstvo Ukrainy 2018: Statystychnyi zbirnyk [Agriculture of Ukraine 2018: Statistical compendium]. Derzhkomstat, Kyiv.

State Statistics Service of Ukraine (2020a). Silske hospodarstvo Ukrainy 2019 : Statystychnyi zbimyk [Agriculture of Ukraine 2019: Statistical compendium]. Derzhkomstat, Kyiv.

State Statistics Service of Ukraine (2020b). Tvarynnytstvo Ukrainy 2019: Statystychnyi zbirnyk [Animal husbandry of Ukraine 2019: Statistical collection]. Derzhkomstat, Kyiv.

Sukharev, J. S. (2011). Identyfikatsija termostabilnoho enterotoksyna Escherichia coli pri kolibakteryoze teliat [Identification of the thermostable enterotoxin of Escherichia coli in calves with colibacteriosis]. Visnyk of Dnipropetrovsk University, Biology, Medicine, 1(2), 114-119 (in Russian).

Tarasenko, N. V., Sylyna, E. A., Kravchenko, Y. A., \& Shtybler, J. V. (2011). Aktualnye aspekty bakteriolohicheskoj diahnostiki v lechenii kampilobakterioza u detej [Current aspects of bacteriological diagnosis and treatment of campylobacteriosis in children]. Zaporizhia Medical Journal, 13(4), 135-136 (in Russian).

Taylor, L. H., Latham, S. M., \& Woolhouse, M. E. (2001). Risk factors for human disease emergence. Philosophical Transactions of the Royal Society B: Biological Sciences, 356(1411), 983-989.

Uhovska, T. M., Gorbatjuk, O. I., Garkavenko, T. O., Ryzhenko, G. F., Andrijashhuk, V. O., Zhovnir, O. M., \& Tjutjun, S. M. (2017). Monitoryng listeriozu tvaryn ta zasoby jogo profilaktyky dlja pidtrymannia biobezpeky v Ukrajini [Monitoring of animal listeriosis and its prevention tools for maintenance of biosafety in Ukraine]. Veterinary Medicine, 103, 222-226 (in Ukrainian).

Ushkalov, V. O., Derjabin, O. M., Kovtun, V. A., Machuskyj, O. V., \& Betlinska, T. V. (2014). Rozrobka naboru dlia vyjavlennia DNK bakterij rodu Listeria metodom polimeraznoji lancjugovoji reakciji “Listeria spp. - PLR-test” [Development of a set to detect DNA bacteria of the genus Listeria method of polymerase chain reaction "Listeria spp. - PCR test"]. Veterinary Biotechnology, 25, 126-129 (in Ukrainian).

Vasilyeva, T. B. (2016). Monitoryng epizootychnoji sytuatsiji z kolibakteriozu v Ukrajini za period 2004-2015 $\mathrm{rr}$. [The monitoring of epizootic situation of colibacteriosis in Ukraine during 2004-2015]. Scientific Messenger of LNU of Veterinary Medicine and Biotechnology, 66, 30-35 (in Ukrainian).

Voida, J. V. (2014). Otsinka chutlyvosti do antymikrobnykh preparativ klinichnykh shtamiv Escherichia coli [Assessment of sensitivity to antimicrobial preparations of clinical strains of Escherichia coli]. Annals of the Mechnikov Institute, 2,79-86 (in Ukrainian). 
Vygovska, L. M. (2018a). Determination Listeria spp. (L. welshimeri, L. grayi, L. murrayi, L. innocua) sensitivity to antibiotics. Journal for Veterinary Medicine, Biotechnology and Biosafety, 4(3), 33-36.

Vygovska, L. M. (2018b). Determination of antibiotic susceptibility of Listeria spp. Journal for Veterinary Medicine, Biotechnology and Biosafety, 4(2), 5-11.

Vygovska, L. M. (2018c). Vyvchennia biolohichnykh vlastyvostej epizootychnykh shtamiv Salmonella spp. [Study of the biological properties of epizootic strains of Salmonella spp.]. Veterinary Biotechnology, 32(1), 71-79 (in Ukrainian).

Vygovska, L. M. (2018d). Rozroblennia zasobu dlia vyjavlennia DNK bakterij vydu Listeria monocytogenes metodom polimeraznoji lancjugovoji reakciji v real'nomu chasi [Development of a DNA detection of bacteria species Listeria monocytogenes by polymerase chain reaction in real time]. Scientific reports of the National University of Life and Environmental Sciences of Ukraine. Veterinary Medicine, Quality and Safety of Livestock Products, 73, 1-9 (in Ukrainian).

Wädekin, K. E. (1990). Private agriculture in socialist countries: Implications for the USSR. In: Grossman, G. (Ed.). Soviet Agriculture, Comparative Perspectives. Smithsonian Institution, Washington. Pp. 243-264.

Wasteson, Y. (2001). Zoonotic Escherichia coli. Acta Veterinaria Scandinavica, 95, 79-84.
Yakubchak, O. M., \& Kobysh, A. I. (2012). Salmonella enteritidis - zbudnyk emerdzhentnoji kharchovoji toksykoinfektsiji [Salmonella enteritidis - pathogen of emergent food toxicoinfection]. Modem Poultry Farming, 116, 9-12 (in Ukrainian).

Yakubchak, O. M., Obshtat, S. V., Mukovoz, V.M., Karpulenko, M. S., \& Gavrylenko, O. S. (2014). Analiz epizootychnoji sytuaciji infekcijnyh hvorob svynej v Ukrajini [Analysis of the epizootic situation of infectious diseases of pigs in Ukraine]. Bulletin of the Poltava State Agrarian Academy, 3, 82-85 (in Ukrainian).

Zarytskyj, A. M., Glushkevych, T. G., \& Bubalo, V. O. (2016). Aktual'nist' sal'monel'ozu v Ukrajini i perspektyva borot'by z nym [Actuality of salmonellosis in Ukraine and the prospect of combating it]. Infectious Diseases, 85, 5-9 (in Ukrainian).

Zhovnir, O. M., Andriiashchuk, V. A., Harkavenko, T. A., Ukhovska, T. M., Mintsiuk, Y. P., \& Tiutiun, S. M. (2019). Monitoryng infektsiinykh khvorob tvaryn bakterialnoji etiologiji na terytoriji Ukrajiny [Monitoring of infectious diseases of bacterial etiology on the territory of Ukraine]. Veterinary Biotechnology, 35, 45-53 (in Ukrainian).

Zinchuk, O. M., Kiselyk, I. O., \& Hudyma, T. V. (2011). Listerioz: Zahroza zloroviu liudyny u XXI storichchi [Listeriosis: Health threat to the XXI century]. Ukrainskyi Medychnyi Almanakh, 14(6), 75-78 (in Ukrainian).

Zotsenko, L. V., \& Volynets, L. K. (2002). Monitorynh shtamiv E. coli serohrupy O:157 [Monitoring of strains E. coli serogroups O:157]. Veterinary Biotechnology, 2, 83-87 (in Ukrainian). 